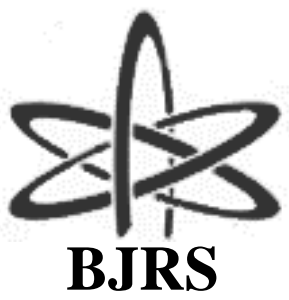

\author{
BRAZILIAN JOURNAL \\ $\mathrm{OF}$ \\ RADIATION SCIENCES \\ 07-02A (2019) 01-14
}

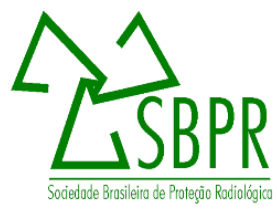

\title{
Ionizing radiation effects in Brazilian grape tree wine
}

\author{
J. A. Pires ${ }^{\text {a }}$ M. N. C. Harder $;$; V. Arthur'; L. C. A. S. Silva ${ }^{\mathrm{c}}$ \\ ${ }^{a}$ Nuclear and Energy Research Institute, 05508-000, São Paulo, SP, Brazil \\ ${ }^{a}$ Technology College of Piracicaba/Food Technology Department, 13414-155, Piracicaba, SP, Brazil \\ ${ }^{a}$ Center of Nuclear Energy in Agriculture/Department of Radiobiology and environment, 13400-970, Piracicaba, SP, \\ Brazil
}

e-mail arthur@cena.usp.br

\begin{abstract}
The aim of this work was to irradiate brazilian grape tree (Myrciaria cauliflora) wines with gamma radiation (Co60) to investigate the effect of radiation on its components and to create a new product with quality for the superior fermented beverages market. For this wine was produced in an artisan way, but with all the care of hygiene and sanitation. The brazilian grape tree was femented for five days and the wine was then filtered and stored in inert material containers then irradiated at 2.5 and $5 \mathrm{kGy}$ doses. The samples were evaluated in relation to the radiation doses used. Physical and chemical analyzes of $\mathrm{pH}$; total and volatile acidity; alcohol content; anthocyanins; tannins and colorimetry were performed. As a result, in most product analysis, had little effect on irradiation, except for anthocyanins and tannins. For this can be concluded that it is possible to develop a new fermented drink based on brazilian grape tree, according to the standards required by the legislation and that the irradiation at the dose of $5 \mathrm{kGy}$ was the sample that shown to have the most effect on the color because it was the one that degraded most molecules of anthocyanins and tannins.
\end{abstract}

Keywords: gamma radiation, beverage aging, physic-chemical parameters beverage, Myrciaria cauliflora.

ISSN: 2319-0612

Accept Submission: 2019-01-21 


\section{INTRODUCTION}

Brazilian grape tree (Myrciaria cauliflora) is a tropical fruit, typically Brazilian, originating in the south-central region [1]. Popularly appreciated for its sensory characteristics in natura, but also for the use in processed products such as jellies, liqueurs and fermented beverages [2].

The most important compounds present in brazilian grape tree are polyphenols, better known as phenolic compounds. These can vary according to the cultivar, the variety, stage of maturation and the climatic conditions. In the bark and in the pulp are founded several phenolic compounds, among them the flavonoids, anthocyanins, tannins and phenolic acids [3]. These are responsible for the protection against light, defense against microorganisms and insects, as the astringency of these compounds presents as efficient antiparasitic, besides being responsible for pigmentation and organoleptic characteristics [4].

Due to its sensorial characteristics, coupled with the need to expand its production and consumption in several countries, brazilian grape tree can be used for the production of alternative ferments [3].

Although the designation wine refers to Brazilian Law 5.823 of November 14, 1973 [5] as "drink from the alcoholic fermentation of sour, fresh and ripe grape must", is permitted by Brazilian Law 7,678 of November 8, 1988 the production of wines of other fruits [6], provided the name of the fruit is indicated on the label after the word wine, such as Brazilian grape tree wine.

Any fruit that contains reasonable levels of sugar is possible to produce a good wine, with flavors characteristic of each fruit [7].

As Brazilian grape tree is a fruit with physic-chemical characteristics similar to grapes, such as tannins and anthocyanins present in its bark, but in greater quantity and presence of fermentable sugars, this fruit is susceptible to fermentation and production of a good wine [7].

The quality of wine often depends on the age of the drink, commonly called aged wines have different organoleptic characteristics, and their quality is superior to wines known as young. It is in the period of aging that the perfumes, colors and flavors strongly characteristic of a given territory, reveal themselves. Only time allows aroma precursors to become perfumes and the bouquet harmonizes with taste [4]. 
Irradiation studies currently focus on the food industry, especially for foods where heat is unviable for its preservation. Irradiation is, among all the conservation processes, the one that has been more investigated [8].

Nuclear radiation is emitted by a radioactive or particulate element, such as alpha and beta, or by gamma radiation. The latter is the most used for food preservation and for aging in beverages such as wines and sugar cane spirit. For these purposes, the use of the Co60 isotope (Cobalt-60) as the source of this radiation is more common $[9,10]$.

However, the irradiation process can be used in wines with different objectives. There are several reasons for this type of procedure, among them are sterilization of the must; changes in the sensorial characteristics of wine; and acceleration of aging [11, 12].

Because of these, this work aimed to produce and irradiate brazilian grape tree wines with gamma radiation (Co60) to create a new product for the market of fermented beverages with quality and to evaluate the effects of the irradiation process on the physicochemical composition of the product.

\section{MATERIALS AND METHODS}

\subsection{Wine preparation}

The fruits of brazilian grape tree (Myrciaria cauliflora) were harvested in the trees belonging to Fazenda Areião, located in the city of Piracicaba in the interior of São Paulo. They were hand picked one by one and stored in plastic containers for transport. Subsequently they were properly sanitized in chlorinated solution.

The crushing for breaking the bark was done manually and the obtained wort was placed in a fermentation vessel.

The must for brazilian grape tree red wine was prepared according to [13] using $24.82 \mathrm{~kg}$ of miture brazilian grape tree and $595 \mathrm{~g}$ of yeasts of the species Saccharomyces cerevisiae were used. Correction of the amount of soluble solids was performed with addition of sucrose until reaching $22^{\circ}$ Brix, using $2.7 \mathrm{~kg}$ of sugar in total. In addition, $2.4 \mathrm{~g}$ of sodium metabisulfate was added for bacterial control. 
The temperature was controlled to be between 28 to $30^{\circ} \mathrm{C}$. The amount of soluble solids was monitored throughout the period of alcoholic fermentation until this value was stabilized, using a portable refractometer.

The shells of the brazilian grape tree remained in contact with the must throughout the alcoholic fermentation, which lasted approximately 20 days.

The reassembly, that is, to submerge the solid part that rises to the surface, was done twice a day, to avoid the vinegary $[14,15]$.

The discovery was made by separating shells and bagasse (solid part) from the liquid. The transfer was carried out three days after fermentation. The liquid was filtered by separating the sludge from the liquid part.

The wine for physical-chemical analysis was bottled in $255 \mathrm{~mL}$ bottles of inert material properly sterilized in boiling water. The containers were sealed and sent to the irradiation process.

\subsection{Wine radiation}

The Gammacell 220 Excel irradiator, MDS, Nordion, by Cobalt 60 source, located at the Center for Nuclear Energy in Agriculture (CENA / USP) was used to treat the samples. The doses 0; 2.5 and $5 \mathrm{kGy}$ were used.

The samples were analyzed at 3 different times 0, 60 and 120 days after irradiation with (Co60).

\subsection{Physic-chemical analysis}

Analyzes of $\mathrm{pH}$, total acidity were performed according to AOAC methodology (1995) [16].

For Volatile Acidity, a specific equipment called Redutec was used for the extraction of all volatile substances contained in brazilian grape tree red wine samples [17]. After extracting the volatile substances from the brazilian grape tree wines, the acetic acid content was determined by titratable acidity [16].

The alcoholic content was measured through the ebuliometer, an apparatus that measures the alcoholic content through the boiling of the liquid and stability in the temperature and with it is obtained the alcoholic degree through the correspondence of the same in the conversion rule [18]. The color of brazilian grape tree red wine samples was evaluated through a digital colorimeter, Minolta brand, 220V, which emits light shots and from these it is possible to measure the 
colorimetric parameters of L (luminosity), a (intensity of red/green) and b (yellow/blue intensity) by the Hunter Lab system with illuminating source D65, calibrated in white porcelain with Y = 93.7; X $=0.3160$ and $\mathrm{y}=0.3323$, according to pre-established standards [19].

Hunter Lab is also a uniform color scale where differences between points are delineated. This space color system is organized in cube form. The $\mathrm{L}$ axis runs from top to bottom. The maximum for $\mathrm{L}$ is 100 , which would correspond to a perfect reflective diffuser. The minimum for $\mathrm{L}$ is zero, which would correspond to black. The axis a and b have no specific numerical limit, so the positive is red, the negative is green, positive $b$ is yellow, negative $b$ is blue $[19,8]$.

Chroma is the relation between the values of $a$ and $b$, where the value of the real color of the analyzed sample is obtained. Hue-Angle is the angle formed between a and b, indicating the color saturation of the sample [8].

For the analysis of Anthocyanins, first the buffer solutions of potassium chloride with $\mathrm{pH} 1.0$ and sodium acetate solution with $\mathrm{pH} 4.5$ were prepared according to the methodology described by [20]. From each sample of brazilian grape tree wine $5 \mathrm{ml}$ was transferred to two $25 \mathrm{ml}$ volumetric flasks; One of the flasks was filled with buffer solution pH1.0 and another with buffer pH4.5.

The solutions were allowed to stand for $15 \mathrm{~min}$ under light and the readings were read at absorbance 520 and 700nm for each spectrophotometer. The concentrations of anthocyanins were expressed as ciadine-3-glucose in mg/L, calculated according to equation (1) [13].

$$
\begin{aligned}
& \text { Antocianin concentration }(\mathrm{mg} / \mathrm{L})=\mathrm{A} * \mathrm{MM} * \mathrm{FD} / \varepsilon^{*} \mathrm{~b} \\
& \mathrm{~A}=(\mathrm{A} 520 \mathrm{~nm}-\mathrm{A} 700 \mathrm{~nm}) \mathrm{pH} 1.0-(\mathrm{A} 520 \mathrm{~nm}-\mathrm{A} 700 \mathrm{~nm}) \mathrm{pH} 4.5 \\
& \mathrm{MM}=449 \mathrm{~g} / \mathrm{mol}(\text { Molar mass of cyanidin-3-glucose }) \\
& \mathrm{ED}=\text { Dilution factor }(50) \\
& \varepsilon=26.900 \mathrm{~L} / \mathrm{mol} / \mathrm{cm}(\text { Extinction coefficient of ciadinin-3-glucose) } \\
& \mathrm{b}=1 \mathrm{~cm}
\end{aligned}
$$

For Tannins, the methodology described by [21] with adaptations was used. $2.5 \mathrm{~mL}$ of brazilian grape tree wine sample was used which were inserted into $10 \mathrm{ml}$ falcon tubes and $7.5 \mathrm{~mL}$ of methanol was added for dilution. This mixture was stirred for 20 minutes in vortex. The tubes were packed in the centrifuge at $4000 \mathrm{rpm}$ for 20 minutes. The supernatant was then removed and placed in $10 \mathrm{~mL}$ volumetric flasks, in which the volume was quenched with methanol. From each extract 
was taken $1 \mathrm{~mL}$ and placed in test tubes. The $1: 1$ vanillin solution was prepared, $50 \mathrm{~mL}$ of $1 \%$ vanillin and $50 \mathrm{~mL}$ of $8 \% \mathrm{HCl}$ in methanol, and $5 \mathrm{~mL}$ of this solution was added to the test tubes. These were covered with aluminum for no losses and allowed to react for $20 \mathrm{~min}$. For calibration of the spectrophotometer, a blank solution was prepared, with $1 \mathrm{~mL}$ of methanol and $5 \mathrm{~mL}$ of $4 \% \mathrm{HCl}$ in methanol, which was used for reading in the apparatus. Subsequently, catechin, methanol and vanillin were measured at catechin dosages $\mathrm{mg} / \mathrm{mL}$ of 0,$0 ; 0.2 ; 0.4$ to 1 of methanol $(\mathrm{mL})$ of $1 ; 0.8$; 0.6 to 0.0 and $5 \mathrm{~mL}$ of $1: 1$ vanillin to be fitted to the standard curve. The readings occurred in the dark and at a wavelength of 500nm.

Statistical analysis was performed using SAS software. The design was a factorial with two factors (three irradiation doses $\mathrm{x}$ three storage period). The results were submitted to analysis of variance, using the F test at the $95 \%$ confidence level. Subsequently, for the causes of significant variations, the Tukey test was applied with 5\% significance [22].

\section{RESULTS AND DISCUSSION}

Table 1 shows the average data obtained in the analysis of Hydrogenionic potential, total acidity, volatile acidity, in samples of brazilian grape tree wine treated with increasing doses of gamma radiation $(\mathrm{Co60})$.

By the results of the Table 1 can observed that with the exception of the $\mathrm{pH}$ values, all other analyses did not present a significant statistical difference between treatments. The $\mathrm{pH}$ values at the doses of 2.5 and $5.0 \mathrm{kGy}$ were the highests when compared with the control, and can verify that the gamma radiation increased the $\mathrm{pH}$, but it is important to note that this increase was not proportional to the increase in the doses of radiation. 
Table 1: Average values found for analyzes of $\mathrm{pH}$, Total acidity, Volatile acidity and Alcohol tenor in irradiated brazilian grape tree wines

\begin{tabular}{lllll}
\hline Dose $(\mathrm{kGy})$ & $\mathrm{pH}$ & $\begin{array}{l}\text { Total acidity } \\
(\mathrm{mg} / \mathrm{l} \text { citric } \\
\text { acid })\end{array}$ & $\begin{array}{l}\text { Volatile acidity } \\
(\mathrm{mg} / \mathrm{l} \text { acetic } \\
\mathrm{acid})\end{array}$ & $\begin{array}{l}\text { Alcohol tenor } \\
\left({ }^{\circ} \mathrm{GL}\right)\end{array}$ \\
\hline 0 (Control) & $3.040 \mathrm{~b} \pm 0.015$ & $20.802 \mathrm{a} \pm 0.041$ & $4.004 \mathrm{a} \pm 0.049$ & $12.070 \mathrm{a} \pm 0.641$ \\
2.5 & $3.360 \mathrm{a} \pm 0.035$ & $20.603 \mathrm{a} \pm 0.040$ & $4.001 \mathrm{a} \pm 0.080$ & $11.830 \mathrm{a} \pm 0.313$ \\
5.0 & $3.340 \mathrm{a} \pm 0.021$ & $20.400 \mathrm{a} \pm 0.025$ & $4.003 \mathrm{a} \pm 0.071$ & $12.230 \mathrm{a} \pm 0.151$ \\
\hline
\end{tabular}

Lower case letters in the same row do not statistically differ at the $5 \%$ level of significance in the Tukey test.

Mean \pm standard deviation

For the decrease observed has as explanation the effect of radiolysis water molecules when they are struck by ionizing radiation. Following the ionization of the water, an electronic rearrangement and the possibility of producing free radicals follow. As these highly reactive forms, the free radicals, originated as a result of the radiolysis of the water, interact chemically with each other, which can later result in rearrangements that give rise to water again [23].

There are no $\mathrm{pH}$ parameters established by the Brazilian legislation for wines, however, the values found are within the $\mathrm{pH}$ range that would prevent growth of acetic bacteria $(\geq 3.0)$, mainly responsible for the effect known as vinegary.

It can be verified that the total acidity is not affected by the irradiation process, because the irradiated samples remain without significant variance in relation to the control.

The main organic acids of brazilian grape tree are: citric, succinic, malic, benzoic, malonic and oxalic. The most apparent among all is citric acid [24, 25]. For this reason the total acidity was expressed as citric acid.

According to Brazilian Ordinance number 229 of October 25, 1988, it establishes a maximum limit of $130 \mathrm{meq} / \mathrm{l}(130 \mathrm{mg} / \mathrm{l})$ of total acidity and $20 \mathrm{meq} / \mathrm{l}(20 \mathrm{mg} / \mathrm{l})$ of volatile acidity. In the present work the values found for total acidity and volatile acidity are within this legislation [5].

It was possible to verify that the gamma radiation (60Co) did not influence the amount of acetic acid, as shown by the statistical analysis, since there was no significant difference. 
The most common occurrence is the esterification of ethyl alcohol with acetic acid [26]. However alcohols of lower proportions in wine can also undergo esterification is the case of the esterification between isopropyl alcohol and acetic acid, which results in isopropyl acetate ester [27].

For alcohol content it was verified that there was no significant difference in the statistic between the doses, as well as between the time of analysis.

In the study of [28] with irradiated sugar cane spirit, the results obtained during the five samples in the period of 390 days of aging showed no significant statistical difference in the alcohol content. In the work of [26] also showed no change over 36 months in sugar cane spirit stored in bottles for alcohol content.

The alcohol content changes if there is oxidation of the ethanol, which passes to acetaldehyde and if it undergoes another oxidation it passes to acetic acid [26].

According to the Brazilian Wine Legislation, the alcohol content of table wines should be between 8.6 and $14^{\circ} \mathrm{GL}$. The mean values found for all samples are within the standards of the legislation [5].

In Table 2, it was possible to observe that as the dose of gamma radiation used increases, the quantity of anthocyanins decreases, as shown by the significant statistical decay. With relation, the tannins do not have difference statistical between the control and dose of $2.5 \mathrm{kGy}$, but the values decrease with increase of doses of gamma radiation.

Table 2: Mean values for amount of anthocyanins and tannins in irradiated brazilian grape tree wine

\begin{tabular}{lll}
\hline Dose $(\mathrm{kGy})$ & $\begin{array}{l}\text { Anthocyanins } \\
(\mathrm{mg} / \mathrm{l})\end{array}$ & Tannins $(\mathrm{mg} / \mathrm{g})$ \\
\hline $0(\mathrm{Control})$ & $72.770 \mathrm{a} \pm 0.660$ & $2.421 \mathrm{a} \pm 0.030$ \\
2.5 & $44.261 \mathrm{~b} \pm 0.960$ & $2.176 \mathrm{a} \pm 0.330$ \\
5.0 & $31.135 \mathrm{c} \pm 0.950$ & $1.663 \mathrm{~b} \pm 0.090$ \\
\hline Lower case letters in the same row do not statistically \\
differ at the 5\% level of significance in the Tukey test \\
Mean \pm standard deviation
\end{tabular}


According to [29, 3], the bark of brazilian grape tree is rich in phenolic compounds, with a concentration of anthocyanins of 314.00 milligrams per $100 \mathrm{~g} /$ fruit, a value close to that found in grape bark $(332.00 \mathrm{mg} / 100 \mathrm{~g}$ of fruit), being able to represent an important source of natural food colorings.

According to [30] during aging the anthocyanins polymerize, a normally unstable reaction, which results in the precipitation of these compounds which consequently decrease color. This polymerization may explain the statistical significance of the decrease in value according to the increase of the dose observed in the present study.

The $\mathrm{pH}$ and total acidity are important in the stabilization of anthocyanins, since these are amphoteric (look for) and according to $\mathrm{pH}$ their coloration and shape change [31].

In an acidic environment the anthocyanins are in the form of salts of oxon, and are generally in the red coloration. If the $\mathrm{pH}$ increases, this pigment will have a quinoidal, purple structure, that is, in an alkaline medium, it will be in the blue color [32].

For the values found in the Tannin analysis, it was possible to verify the reduction of the tannins both in the increase of the irradiation dose and in the course of time.

This behavior in grape wines is unusual. According to [33] over time, grape wines increase the amount of tannins. In irradiated grape wines, the increase of tannins was observed, especially in the dose of 3 and $6 \mathrm{kGy}[34]$.

However, according to [33], in wine can occur changes of the enzymatic type, this type is called oxidative casse. It occurs in past point grapes. The wine generated from these fruits becomes dark and cloudy in contact with the air. This turbidity is caused by the presence of polyphenoloxidase in high content, which causes the insolubility of tannin and coloring matters. Wines with this problem acquire red, amber, or just dark coloration, with cooked taste and a bit of bitter. This change can be called "woodworking".

In Table 3, it was observed from the data of the colorimeter reading, in relation to the radiation doses used, that none of the treatments significantly altered the samples. 
Table 3: Mean values found in the colorimetric analysis of irradiated brazilian grape tree wine

\begin{tabular}{lccccr}
\hline & \multicolumn{5}{c}{ Parameters } \\
\cline { 2 - 6 } Dose $(k G y)$ & $\mathrm{L}$ & $\mathrm{a}$ & $\mathrm{b}$ & Chroma & Hue Angle \\
\hline 0 (Control) & $19.97 \mathrm{a} \pm 0.42$ & $1.16 \mathrm{a} \pm 0.11$ & $4.01 \mathrm{a} \pm 0.91$ & $4.17 \mathrm{a} \pm 0.71$ & $1.26 \mathrm{a} \pm 0.07$ \\
2.5 & $20.02 \mathrm{a} \pm 0.34$ & $1.01 \mathrm{a} \pm 0.18$ & $3.68 \mathrm{a} \pm 0.68$ & $3.82 \mathrm{a} \pm 0.45$ & $1.21 \mathrm{a} \pm 0.03$ \\
5.0 & $20.11 \mathrm{a} \pm 0.25$ & $1.15 \mathrm{a} \pm 0.06$ & $3.73 \mathrm{a} \pm 0.73$ & $3.91 \mathrm{a} \pm 0.68$ & $1.20 \mathrm{a} \pm 0.01$ \\
\hline
\end{tabular}

Lower case letters in the same row do not statistically differ at the 5\% level of significance in the Tukey test

Mean \pm standard deviation

The lack of difference in the coloration between doses does not match the results found in the analyzes of anthocyanins and tannins presented in Table 2. The anthocyanins are the main responsible for the coloration.

One can perceive the difference of color with naked eye by Figure 1 and 2.

Figure 1 and 2: Samples of dry red wine from brazilian grape tree irradiated
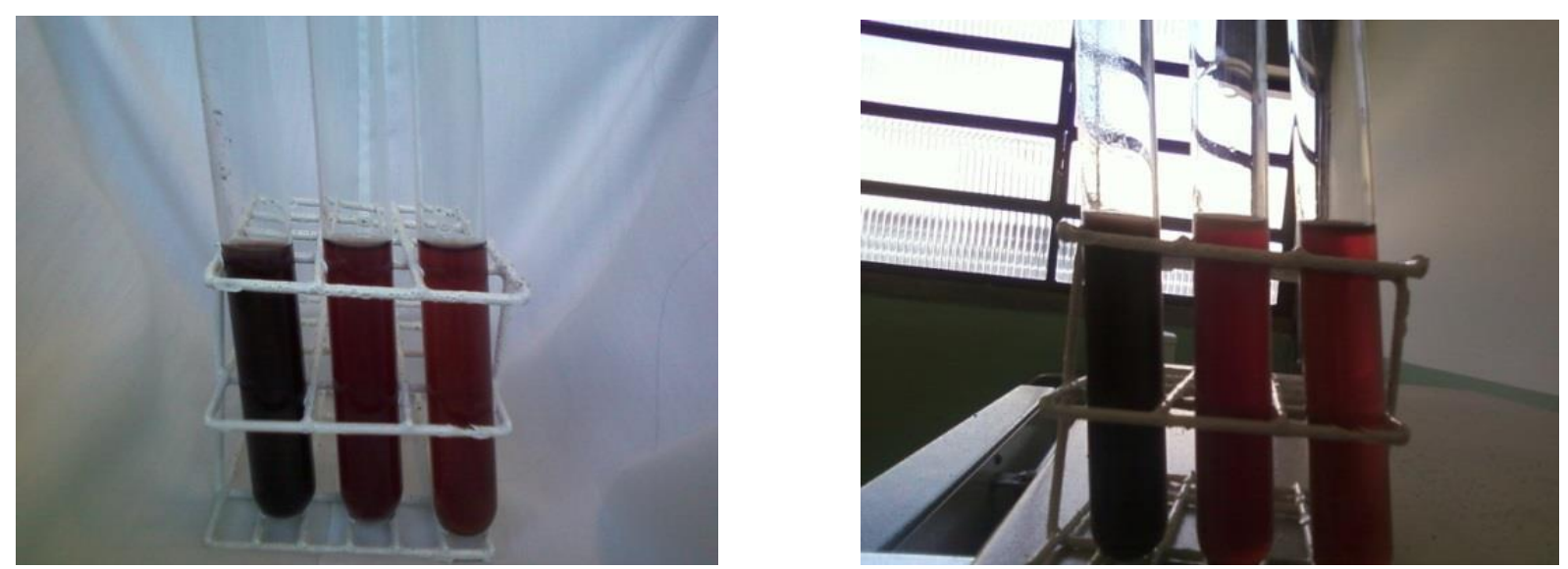

In the work of [34] it was verified that red wines irradiated with 1.0; 3.0 and 6.0kGy and analyzed with colorimeter, when the dose of radiation increased the coloring modified tending more towards the yellow, because there was increase of the Chroma as increase of the dose. 


\section{CONCLUSION}

The conclusion was that it is possible to develop a new fermented drink based on brazilian grape tree, according to the standards required by the legislation and that the irradiation at the dose of $5 \mathrm{kGy}$ was the sample that shown to have the most effect on the color because it was the one that degraded most molecules of anthocyanins and tannins.

\section{REFERENCES}

1. SASSO, S. A. Z.; CITADIN, I.; DANNER, M. A. Propagação de Jabuticabeira por estaquia. Rev Bras Frut, v. 32, p. 577-583, 2010.

2. MACHADO, A. M. R.; SANTIAGO, M. C. P. A.; BORGUINI, R. G.; GODOY, R. L. O.; GOUVÊA, A. C. M. S.; PACHECO, S.; NASCIMENTO, L. S. M. D. Identificação de Antocianinas na Casca de Jabuticaba Liofilizada. Embrapa, São Paulo, Brazil. 2104. Available at:<http://ainfo.cnptia.embrapa.br/digital/bitstream/item/91423/1/2013-109.pdf>. Last accessed: 11 Sept. 2017.

3. GUEDES, M. N. S. Diversidade de acessos de jabuticabeira sabará em diamantina por meio de caracterização biométrica e físico-química dos frutos e fisiológica das sementes, Universidade Federal do Jequitinhonha, Diamantina, Brazil. 2009.

4. CALÓ, A.; CERNILli, D.; LANATI, D.; MARTELli, G.; SABELliCO, M.; SCIENZA, A.; VACCARINI, G. A. Escolha, compra, serviço, degustação, manual do sommelier. Globo, São Paulo, Brazil. 2011.

5. BRAZIL. Portaria no 229, de 25 de outubro de 1988. Avisa, Brasilia, Brazil. 1988. Available at:<http://www2.agricultura.rs.gov.br/uploads/126989498929.03_enol_p_229_88_mapa.doc+\&cd= $3 \& \mathrm{hl}=\mathrm{pt}-\mathrm{BR} \& \mathrm{ct}=\mathrm{clnk} \& \mathrm{gl}=\mathrm{br}>$. Last accessed: 11 Sept. 2017.

6. BRAZIL. Lei no 7.678, de 08 de Novembro de 1988. Republic Presidency, Brasilia, Brazil. 1988. Avilable at:<http://www.planalto.gov.br/ccivil_03/leis/1980-1988/L7678.htm>. Last accessed: 11 Sept. 2017. 
7. CORAZZA, M. L.; RODRIGUES, D. G.; NOZAKI, J. Preparação e Caracterização do vinho de laranja. Quim Nova, v.24, p. 449-452, 2001.

8. HARDER, M. N. C. Efeito da radiação gama em proteínas alergênicas de ovos de galinhas poedeiras, Centro de Energia Nuclear na Agricultura, Piracicaba, Brazil. 2009.

9. URBAIN, W. M. Food Irradiation. Academic, New York, USA, 1986.

10. MEDEIROS, M. A. Radiação Nuclear. 2015. Available at:http://www.quiprocura.net/radianuclear.htm. Last accessed: 11 Sept. 2107.

11. LEITE, D. T. S. Avaliação dos efeitos da radiação gama na qualidade de abacaxi (Ananas comosus (L.) Meer) cv. Smooth Cayenne minimamente processado, armazenado em diferentes temperaturas e embalagens, Centro de Energia Nuclear na Agricultura, Piracicaba, Brazil (2006).

12. M. D. C. A. Souza, Identificação, quantificação e comparação das substâncias químicas responsáveis pelos aromas da cachaça de alambique e do rum comercial tratados pelo processo de irradiação, Instituto de Pesquisas Energéticas e Nucleares, São Paulo, Brazil (2006).

13. FORTES, G. A. C. Análise multiparimétrica da qualidade dos frutos, mostos e vinhos de jabuticaba, Universidade Federal de Goiás, Goiânia, Brazil. 2012.

14. RIZZON, L. A.; ZANUZ, M. C.; MIELE, A. Evolução da acidez durante a vinificação de uvas tintas de três regiões vitícolas do Rio Grande do Sul. C Tecn Alim, v. 18, p. 179-183, 1998.

15. GUERRA, C. C.; MANDElli, F.; TONIETTO, J.; ZANUS, M. C.; CAMARGO, U. A. Conhecendo o essencial sobre uvas e vinhos. Embrapa, Bento Gonçalves, Brazil, 2009.

16. AOAC. Official methods of analysis of AOAC International. AOAC, Washington, USA, 1995.

17. PEREIRA, N. E.; CARDOSO, M. G.; AZEVEDO, S. M.; MORAIS, A. R.; FERNANDES, W.; AGUIAR, P. M. Compostos secundários em cachaças produzidas no estado de Minas Gerais. C Agrotec, v. 27, p. 1068-1075, 2011.

18. NOGUEIRA, A.; PRESTES, R. A.; SIMÕES, D. R. S.; DRILlEAU, J. F.; WOSIACKI, G. Análise dos indicadores físico-químicos de qualidade da sidra brasileira. SEMINA, v. 24, p. 289$298,2003$.

19. HUNTERLAB. Hunter L, a, b Color Sacale Applications. 2008. Available at:<http://hunterlab.com/appnotes/an08_96a.pdf> Last accessed: 13 Sept. 2017. 
20. ALIBERTI, N. C. M. Influência da homogeinização a alta pressão sobre a retenção de antocianinas presentes na polpa de açaí (Euterpe oleraceae Mart.), Escola Politécnica da Universidade de São Paulo, São Paulo, Brazil, 2009.

21. PRICE, M. L.; HAGERMAN, A. E. Tannin contet of cawpeas, chickpeas, pigeon peas, and human mung beans. J Agric Food Chem, v. 28, p.459-461, 1980.

22. SAS. SAS Software. Version 9.1. SAS Institute Inc., Cary, USA, 1999.

23. DIELH, J. F. Safety of irradiated food. Marcel Dekker, New York, USA, 1995.

24. JHAM, G. N.; FERNANDES, S. A.; GARCIA, C.F.; PALMQUIST, D. Comparison of GC and HPLC for quantification of organic acids in two jaboticaba (Myrciaria) fruit varieties. Quim Nova, v.30, p.1529-1534, 2007.

25. GUIMARÃES, D. P. Avaliação de estresse e do potencial fermentativo de isolados de Saccharomyces na microvinificação da jabuticaba, UFLA, Lavras, Brazil, 2006.

26. PARAZZI, C.; ARThUR, C. M.; LOPES, J. J. C.; BORGES, M. T. M. Avaliação e caracterização dos principais compostos químicos da aguardente de cana-de-açúcar envelhecida em tonéis de carvalho (Quercus sp.),” C Tecn Alimentos, v. 28, p. 193-199, 2008.

27. KOBAYASHI, M. L. Caracterização dos compostos de aromas produzidos por leveduras com potencial de utilização na indústria de alimentos, Universidade Federal Tecnológica do Paraná, Londrina, Brazil, 2011.

28. MIRANDA, M. B. Avaliação físico-química de cachaças comerciais e estudo da influência da irradiação sobre a qualidade da bebida em tonéis de carvalho, Escola Superior de Agricultura Luiz de Queiroz, Piracicaba, Brazil, 2005.

29. TERCI, D. B. L. Aplicações analíticas e didáticas de antocianinas extraídas de frutas, UNICAMP, Campinas, Brazil, 2004.

30. DAVID, J. M. P.; DAVID, J. P.; SANTOS, V. L. C. S.; SANTOS, M. L. S.; MOTTA, M. D. Resveratrol: ações e benefícios à saúde humana. Dialog Cienc, v. 5, p. 1-11, 2007.

31. FREITAS, D. M. Variação dos compostos fenólicos e de cor dos vinhos de uva (Vitis vinífera) tintas em diferentes ambientes, Universidade Federal de Santa Maria, Santa Maria, Brazil, 2006.

32. BOBBIO, P. A.; BOBBIO, F. O. Química do Processamento de Alimentos, Ed. Varela, Campinas, Brazil, 2001. 
33. AQUARONE, E.; BORZANI, W.; SCHIMIDELL, W.; LIMA, U. A. Lima. Biotecnologia Industrial: Biotecnologia na produção de alimentos. Ed. Blucher, São Paulo, Brazil (2001).

34. PIRES, J. A.; SCANHOLATO, M. Envelhecimento de vinho por irradiação gama (Co60), Faculdade de Tecnologia de Piracicaba, Piracicaba, Brazil, 2011. 